\title{
GOLD-TESTING IN GOLD TREATMENT OF CHRONIC POLYARTHRITIS RESULTS OF CONTINUED EXPERIMENTS
}

\author{
BY \\ TORE SVANBERG \\ From the Medical Clinic, Norrköping Hospital, Norrköping, Sweden \\ Director: L. Brahme, M.D.
}

(RECEIVED FOR PUBLICATION APRIL 15, 1952)

At the Pensions Board Department of the Norrköping Hospital tests with aurothion are now carried out as a routine measure during courses of gold treatment. The method has already been described (Svanberg, 1950).

\section{Method}

We use aurothion dilutions of $1: 1,1: 3,1: 5$, and $1: 10$, and, for purposes of control, the same dilutions of 6.5 per cent. sodium thiosulphate solution.* With a die in the shape of a thin circle with an interior diameter of $5 \mathrm{~mm}$., eight circles are stamped on the skin of one shoulder, four in an upper and four in a lower row, for the aurothion and the sodium thiosulphate, respectively. Into these circles are injected intracutaneously sufficient amounts of each dilution to produce a papule that fills the circle to the inner margin. This requires roughly $0.03 \mathrm{ml}$. To obtain a papule that fits into the circle outlined, the point of the needle should be inserted somewhat eccentrically into the circle. The readings are taken after 20 to $30 \mathrm{~min}$. An oedematous papule of from $5 \times 5$ to $10 \times 10 \mathrm{~mm}$. with a greater or lesser reddened marginal zone is recorded as $(+)$, a papule of from $10 \times 10$ to $15 \times 15 \mathrm{~mm}$. as + , and a papule of from $15 \times 15$ to $20 \times 20 \mathrm{~mm}$. as ++ , in accordance with the marking system generally used in the diagnosis of allergies. The reading is recorded with regard to the size of the control papule. If, for example, this latter is $(+)$ and the aurothion papule is + , the reaction is recorded as $(+)$.

All recent admissions to the department have been tested, and tests are repeated fortnightly on patients receiving gold salt injections. Gold therapy is not instituted until the testing has been carried out.

The reactions frequently vary as the tests are repeated. The reactions may to the same dilutions become either stronger or weaker; a positive reaction may appear with a weaker dilution than previously, or may disappear with the weaker dilutions. In some cases the reactions are unchanged. The purpose of the present method is to establish a difference between the incidence of complications in those cases that show increasing sensitivity and those that show decreasing sensitivity during the course of the treatment. On the basis of this one would be able to preclude complications by varying or withdrawing the gold treatment.

* The sodium thiosulphate solutions, sterilized by a specific procedure, were placed at our disposal by courtesy of the firm of procedure, . Astra.
Material

204 patients were treated with gold therapy during hospitalization (usually for 2 months) at the Pensions Board Department at the Norrköping Hospital during the period August, 1949, to April, 1951. Aurothion was received by 144 patients, myoral by 53, aurodetoxin by four, and aurothion and myoral in turn by three patients.

About 4 to 6 months after discharge from hospital all patients treated with gold therapy were sent questionnaires on their condition after discharge, the onset and duration of eventual symptoms, fever reaction, appearance of the skin in the event of rash, and the name of the physician consulted. In the event of complications these physicians were requested to supply data on the symptoms and diagnoses. The questionnaire was filled up by all but two of the patients.

The incidence of complications is in all probability reported to its full extent, since the questionnaires were sent out at such intervals that no symptoms would be forgotten by the patients, and late complications could also be included. The various types of complication are listed in Table I.

TABLE I

TYPE AND NUMBER OF COMPLICATIONS IN GOLD TREATMENT

\begin{tabular}{|c|c|c|c|c|}
\hline \multirow{3}{*}{ Type of Disease } & \multicolumn{4}{|c|}{ Number of Cases with Complications } \\
\hline & \multicolumn{2}{|c|}{ During Treatment } & \multicolumn{2}{|c|}{ After Discharge } \\
\hline & $\begin{array}{c}\text { After } \\
\text { one } \\
\text { injection }\end{array}$ & $\begin{array}{c}\text { After } \\
\text { several } \\
\text { injections }\end{array}$ & $\begin{array}{c}\text { After } \\
\text { one } \\
\text { injection }\end{array}$ & $\begin{array}{c}\text { After } \\
\text { several } \\
\text { injections }\end{array}$ \\
\hline Stomatitis, glossitis. . & 4 & 7 & 1 & 6 \\
\hline Herpes labialis & & 1 & & 2 \\
\hline Gastritis $\quad \ldots$ & 4 & 10 & & 1 \\
\hline Enteritis & 4 & 9 & & 1 \\
\hline Metallic taste & & 5 & & \\
\hline Pruritus $\quad \cdots$ & & 7 & & \\
\hline Pruritus exanthema & 6 & 30 & & 18 \\
\hline Anaemia & & 1 & & 2 \\
\hline Leucopenia .. & 1 & 12 & & \\
\hline Thrombocytopenia. . & & 2 & & \\
\hline Migraine & & 1 & & \\
\hline Cephalgia $\quad \ldots$ & 1 & 3 & & \\
\hline
\end{tabular}


Complications during and after the gold treatment were noted in 89 cases ( 43.6 per cent.).

The complications began during hospitalization in 71 cases, and in twelve cases there was one form of complication during hospitalization, and a different type appeared some time after discharge, viz. stomatitis and gastritis during hospitalization, and pruritus and exanthema later on.

Complications which only developed some time after discharge were recorded in eighteen cases.

In three instances BAL treatment was necessary during hospitalization and all these cases were free from symptoms on discharge. None of the complications that developed after discharge was severe enough to require hospital care.

In eleven of the cases with complications these appeared immediately after the first gold injection. As these patients were thus tested only once before the onset of the complication, namely, before this initial injection, the inethod described with repeated tests was not practicable, and a potential increased sensitivity to gold salt was not demonstrable beforehand.

Furthermore, in six other patients a complication occurred after the second injection, but these, either by inadvertence or owing to their absence, were not tested between the first and second injections, and may therefore be referred to the same group as the eleven patients mentioned above. This last group of seventeen cases will be taken up for further discussion below.

\section{Variations in Reactions during Gold Treatment}

In most cases there is a change in the degree of the reactions in immediate association with, or shortly after, the first appearance of a complication. The following five cases will serve as illustrations. Reading from left to right in the tables below, the reactions correspond to the dilutions $1: 1,1: 3$, $1: 5$, and $1: 10$.

In the first case the reactions subsided with the onset of complications.

Record No. 110/50.

\begin{tabular}{l|c|c}
\hline Date of test & Reaction & Aurothion (ml.) \\
\hline April 25 & $(+)-\quad-\quad-$ & 2 \\
May 9 & $(+)(+)--$ & 4 \\
& $(+)(+)(+)(+)$ & 6 \\
May 23 & 6 \\
May 26: diarrhoea, urticarial rash. & Withdrawn \\
May 27: BAL in full dosage. & \\
June 6 & $(+)-$ - & \\
August 2 & - & \\
\hline
\end{tabular}

In the second case the reactions increased after the start of complications and subsequently decreased:

Record No. 19/50.

\begin{tabular}{c|c|c}
\hline Date of test & Result & Aurothion (ml.) \\
\cline { 1 - 2 } January 24 & $(+)(+)(+)-$ & 2 \\
4
\end{tabular}

February 10: gastro-enteritis

February 13: urticarial rash

Withdrawn

February $21+(+)(+)(+)$

March 7

In the third case the reactions decreased in association with the complication, and increased again during a later tentative gold treatment. Subsequently a new complication arose:

Record No. 10/50.

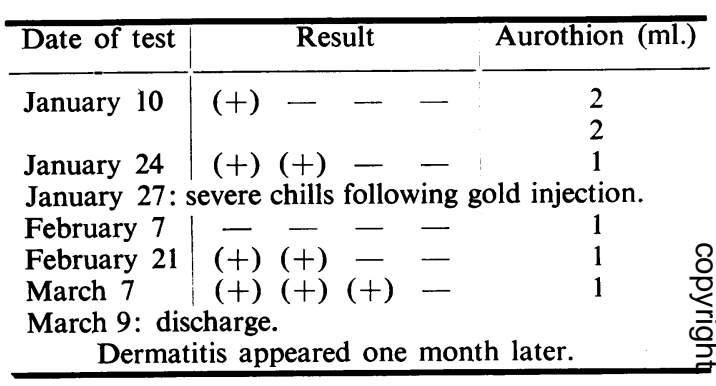

The sensitivity of the organisms to gold salt has thus changed in these cases; a desensitivization has $\stackrel{\mathbb{Q}}{\varnothing}$ occurred. This also agrees with the clinical $\overrightarrow{\overrightarrow{0}}$ improvement which often appears in association 3 with the start of the complications.

In some instances, however, the reactions continue to increase even after the onset of the colnplication. In several cases there may then after some time appear still another complication, as shown in the two following examples:

Record No. $18 / 50$.

\begin{tabular}{|c|c|c|c|c|c|}
\hline Date of test & \multicolumn{4}{|c|}{ Result } & Aurothion (ml.) \\
\hline January 24 & $(+)$ & 一 & - & - & $\begin{array}{l}2 \\
4\end{array}$ \\
\hline February 7 & $(+)$ & - & - & - & $\begin{array}{l}5 \\
5\end{array}$ \\
\hline
\end{tabular}

February 24: gingivitis.

\begin{tabular}{l|lll} 
February 27 & + & $(+)$ & -
\end{tabular}

2

\begin{tabular}{l|cc} 
March 7 & $+(+)-$ \\
March 16: discharge.
\end{tabular}

Soon afterwards stomatitis and urticaria developed and persisted several weeks. 
Record No. 30/50.

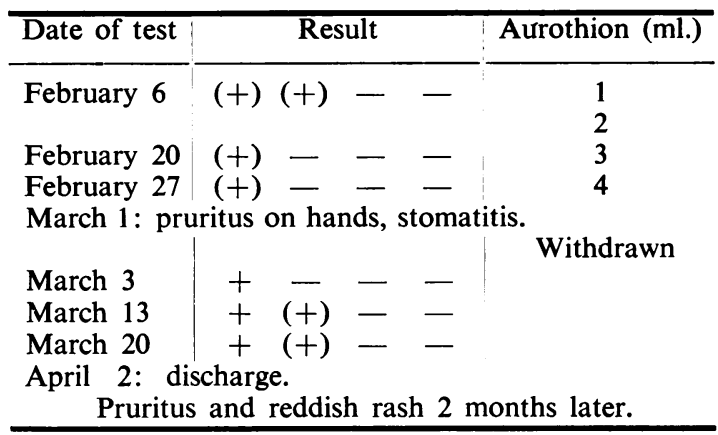

This correspondence between the increasing sensitivity in the skin reactions and the start of a complication is not without exception. One of the reasons for this would seem to be that when the gold treatment is discontinued in connection with discharge from the hospital, and the skin reactions eventually tend to increase, the organism has not as yet become sufficiently sensitized to produce an allergic reaction in one or several organs.

\section{Variations in Reactions in Cases not Treated with Gold Therapy (Controls)}

We have, furthermore, according to the same procedure as described above, tested a number of patients who had not received gold treatment. The reactions in these cases sometimes increased and sometimes decreased, and some remained unchanged. This would thus show that the reactions appear erratically and without causal connection with the amount of gold salt injected.

However, in a couple of gold-treated cases it was found that the small amount of gold salt injected intracutaneously at the tests sufficed to induce a sensitivity, as illustrated by the following case.

Record No. $299 / 50$.

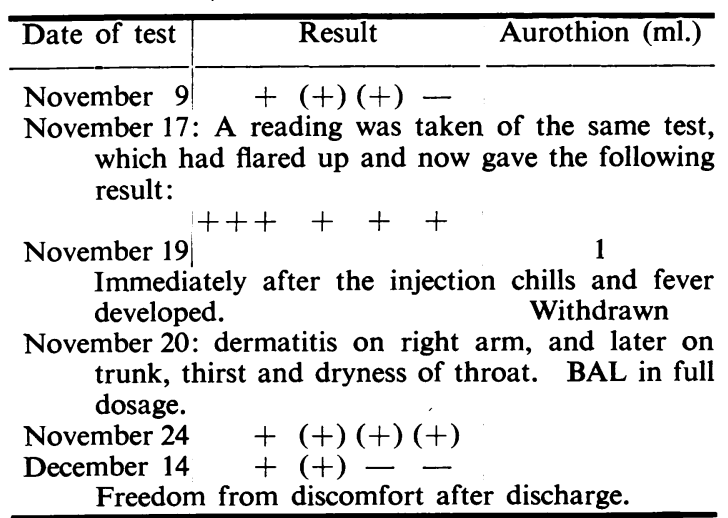

In this case the intracutaneously injected dose of gold salt produced a sensitivity manifested after 8 days in an exacerbation at the site of injection. The intravenous injection of aurothion 2 days later gave an immediate and marked allergic reaction.

It is thus impossible to obtain a series of non-gold treated cases, as the cutaneous test is in itself a gold treatment with small doses.

In this connection, it should be pointed out that with the method described above the reactions are always of the immediate type, and disappear about one hour after the beginning of the cutaneous test.

\section{Results of Analysis of Tested Cases}

187 cases were tested three or more times during hospitalization and received two or more gold injections during this period, the tests being performed at regular intervals during the course of treatment. An analysis of this group gives an idea of the usefulness of this method as a guide in avoiding complications. The results are set out in Table II.

TABLE II

COMPARISON BETWEEN CHANGE IN REACTION IN CASES WITHOUT AND CASES WITH COMPLICATIONS

\begin{tabular}{|c|c|c|c|c|c|}
\hline \multirow{2}{*}{$\begin{array}{c}\text { Change in } \\
\text { Reaction }\end{array}$} & & \multicolumn{2}{|c|}{$\begin{array}{c}\text { Without } \\
\text { Complications }\end{array}$} & \multicolumn{2}{|c|}{$\begin{array}{c}\text { With } \\
\text { Complications }\end{array}$} \\
\hline & & No. & Per cent. & No. & Per cent. \\
\hline Decrease .. & .. & 66 & 88 & 9 & 12 \\
\hline No Change & $\ldots$ & 27 & 54 & 23 & 46 \\
\hline Increase .. & $\ldots$ & 22 & $35 \cdot 5$ & 40 & $64 \cdot 5$ \\
\hline Total & $\ldots$ & 115 & & 72 & \\
\hline
\end{tabular}

As appears from the foregoing, the reactions frequently change during the course of the treatment. The current sensitivity to gold has been determined on the basis of the relationship between the latest test and the test carried out before the initiation of the gold treatment. Accordingly, the reactions may be on the decrease compared with one or more immediately preceding tests, but may be stronger than the initial test; the reactions are then considered as increased.

Table II shows that complications occur in 64.5 per cent., or roughly two-thirds of cases in which the reactions tend to increase. In cases that show decreased reactions complications occur in only 12 per cent. In cases with unchanged reactions complications occur in 46 per cent., or nearly half.

In the preliminary investigation, the figures for the first group (cases with increasing reactions) were 95 per cent., considerably higher than those in the 
present study. In the two other groups the figures tally better ( 5 and 44 per cent. respectively).

The result of this analysis is that in cases in which the cutaneous reactions show a trend to decrease gold treatment may be given with only a 12 per cent. risk of complications. These cases would thus be appropriate for continued gold treatment by outside physicians after discharge from the hospital. In the present series these cases constitute 40 per cent. of all patients treated with gold.

In the remaining patients the gold treatment should be pursued extremely cautiously with careful observation of the patient and the laboratory findings, particularly when the reactions increase in strength. In this latter group it would seem advisable to withdraw the treatment until the reactions decrease to a reassuring level.

Gold treatment is at present being carried out according to these principles at the Pensions Board Department of the Norrköping Hospital. The results will be published at some future date.

In some cases, however, the complications arise at once after the initial injection of gold salt. Unfortunately, one can draw no conclusions from the degree of the reactions to the initial cutaneous test, since complications appear as frequently in cases showing weak reactions at this point as in those showing strong ones. In some of these markedly gold-sensitive cases one may guess at probable developments by observing the site of the preceding cutaneous test. If flare-up occurs, gold should not be administered. Two cutaneous tests may also be carried out with a few days' interval before the gold treatment is begun, in order to assess the patient's sensitivity.

\section{Summary}

In continued experiments with gold-testing in a series of 187 cases, a fairly definite idea of the risk of complications was obtained in roughly two-thirds of the patients examined (137 cases: $73 \cdot 2$ per cent.).

Complications were noted in 64.5 per cent. of those patients who showed increased reactions to repeated tests during a course of gold treatment, while complications followed in only 12 per cent. of those patients who showed decreased reactions.

A change in the degree of the reactions oftenco. appeared in association with a complication; these variations are described.

Suggestions based on the results of the tests are? made regarding the amount of gold that may safely be given.

\section{REFERENCE}

Svanberg, T. (1950). Annals of the Rheumatic Diseases, 9, 221.

Réactions de sensibilité à l'or dans la chrysothérapie dél'arthrite rhumatismale-Résultats de la suite des expériences

RÉSUMÉ

Après avoir continué les réactions de sensibilité auxsels d'or dans 187 cas, on a pu se faire une bonne idée $\vec{\omega}$ sur le danger de complications chez deux tiers à peu près des malades examinés ( 137 cas; 73,2 pour cent).

Au cours de la chrysothérapie on a noté des com- -6 plications dans 64,5 pour cent des cas chez qui les? réactions répétées ont montré une sensibilité croissanteet dans 12 pour cent seulement des cas avec sensibilités décroissante.

L'intensité de la réaction variait souvent selon lâे complication; l'auteur décrit ces variations.

L'auteur suggère, pour des raisons de sécurité, que leş్ résultats de ces réactions devraient guider la posologie des sels d'or.

Reacciones de sensibilidad al oro en la crisoterapia dę artritis reumatoide-Resultados de los experimentrso continuados

\section{Sumario}

Al continuar los experimentos con reacciones dê sensibilidad a sales de oro en un grupo de 187 enfermos $\varrho$ el autor pudo hacerse una idea bastante clara sobre el riesgo de complicaciones en aproximadamente dos terceras partes de los enfermos estudiados (137 casos? $73,2 \%$ ).

En el curso de crisoterapia complicaciones fueror observadas en el 64,5\% de los enfermos cuyas reaccioneș repetidas mostraron una sensibilidad creciente y en eह $12 \%$ sólo de los con sensibilidad decreciente.

A menudo la intensidad de la reacción cambiaba en asociación con la complicación; el autor describe estaş variaciones.

El autor sugiere que, por razones de seguridad, los resultados de estas reacciones deberían guíar la posología de los sales de oro. 